\title{
OPTIMIZATION OF PEROXIDASE ACTIVITY OF TURNIP (BRASSICA RAPA) USING RESPONSE SURFACE METHODOLOGY
}

\author{
- Research paper -
}

\author{
Amel DAHDOUH, Mostapha BACHIR-BEY ${ }^{1}$, Djamel Edine KATI \\ Laboratoire de Biochimie Appliquée, Département des Sciences Alimentaires, Faculté des Sciences \\ de la Nature et de la Vie, Université de Bejaia, 06000 Bejaia, Algeria
}

\begin{abstract}
The present study is focused on the determination of optimized activity conditions of peroxidase (POD) of turnip (Brassica rapa). The enzyme is extracted from turnip with $0.5 \mathrm{M} \mathrm{Na} \mathrm{HPO}_{4}(\mathrm{pH} 7.0)$. Peroxidase activity is evaluated by monitoring the oxidation of guaiacol to tetraguaiacol in the presence of hydrogen peroxide $\left(\mathrm{H}_{2} \mathrm{O}_{2}\right)$. Before the optimization of peroxidase activity from a turnip by response surface methodology (RSM), a preliminary step is conducted for each studied parameter ( $\mathrm{pH}$, temperature, and $\mathrm{NaCl}$ concentration). Further, RSM following BoxBehnken design is used in order to refine the optimization of the conditions. Response surface analysis showed that parameter values with the highest peroxidase activity are $5.9,29.8^{\circ} \mathrm{C}$, and $1.07 \mathrm{M}$ for $\mathrm{pH}$, temperature, and $\mathrm{NaCl}$, respectively. Under these experimental conditions, peroxidase activity is found to be $4027.25 \mathrm{U} / \mathrm{mg}$. The obtained experimental value agrees with that of the calculated one, indicating the pertinence of the developed model for the optimization of peroxidase activity.
\end{abstract}

Keywords: Peroxidase activity, turnip, optimization, response surface methodology

\section{INTRODUCTION}

Peroxidases (POD) is belonging to oxidoreductase enzymes that responsible for catalyzing reactions in which $\mathrm{H}_{2} \mathrm{O}_{2}$ is the acceptor of hydrogen atoms and another compound is a donor (Ikehata et al., 2005; Passardi et al., 2007). According to their amino acid sequences, non-animal peroxidases are divided into three groups: ascorbate type (class I), fungal secretory (class II), and guaiacol type that is synthesized by plants (class III) (Das et al., 2011). The specificity of POD to its substrate is high, but it has low specificity to the hydrogen donor (Passardi et al., 2007). Peroxidases are implicated in several plant functions such as hormone regulation, plant development, defense mechanisms, lignin biosynthesis, and indoleacetic acid degradation (Chisari et al., 2007; Manu and Rao, 2009; Pandey et al., 2017). However, the release of POD from plant tissues is responsible for the oxidation of a wide range of phenolic compounds, such as guaiacol, catechol, pyrogallol, catechin, and chlorogenic acid (Onsa et al., 2004). It is well known that many factors affect enzymatic activity in fruits and vegetables and which can be

Received: 24.07 .2020 .

Accepted in revised form: 12.10 .2020 divided into physical and chemical parameters such as temperature, $\mathrm{pH}$, substrate, and composition of the medium (Shu et al., 2016; Pandey et al., 2018). The enzyme activity is also influenced by the season, the stage of development, and the use of pesticides and fertilizers (Horotan and Oancea, 2013; SerranoMartínez et al., 2014). The studies on peroxidases provided from different plants such as turnip shown that physicochemical parameters, as well as the used substrate, produce significant variations on kinetic properties of enzymes (SerranoMartínez et al., 2008; Zeyadi and Almulaiky, 2020).

Traditional optimization methods are complex processes for multi-variable systems; they permit to examine one factor at a time in which all others are fixed at the same levels. It takes a lot of time and can lead to bad conclusions. While Response Surface Methodology (RSM) is a helpful statistical and mathematical technique for studying and modeling the influence of numerous variables on responses, and widely useful to optimize processes (Tsapatsaris and Kotzekidou, 2004; Benkerrou et al., 2018; Saci et al., 2018). This method permits to improve the statistical interpretation and reveal the interaction between the studied variables while

${ }^{1}$ Corresponding author. E-Mail address: bachirbeymustapha@gmail.com 
reducing the number of required essays (Yim et al., 2012). The RSM is widely used to optimize synthesis of bioactive molecules, extraction of desired compounds, and activity of enzymes (Yamaguchi et al., 2006; Zhang et al., 2017; Pramana et al., 2018).

To the best of our knowledge, this work is the first study concerning the enzymatic activity

\section{MATERIALS AND METHODS}

\section{Extraction of crude enzyme}

The turnip samples used in this study are from Bejaia department (North of Algeria). The turnip roots were cleaned and crushed, then homogenized with $1 / 2(\mathrm{w} / \mathrm{v})$ citrate-phosphate buffer solution (0.5M, pH6.0) by ultra-turrax for $2 \mathrm{~min}$. The homogenate was centrifuged (Sigma 2-16K, Germany) under $4^{\circ} \mathrm{C}$ at $5000 \mathrm{rpm}$ for $10 \mathrm{~min}$ and the supernatant containing peroxidases was transferred to another tube.

\section{Determination of protein concentration}

Total soluble proteins were measured by a colorimetric assay based on measuring the absorbance of dye Coomassie Brilliant Blue G-250 bonded to basic amino acid residues (arginine, histidine, and lysine) Bradford (1976). The absorbance was measured at $595 \mathrm{~nm}$ using a UVVIS spectrophotometer (UviLine 9400, France) and results are expressed referring to Bovine serum albumin (BSA).

\section{Determination of peroxidase activity}

POD activity was determined based on the absorbance of tetraguaiacol formed from guaiacol in the presence of hydrogen peroxide within $1 \mathrm{~min}$. The reaction mixture consisted of $100 \mu \mathrm{L}$ of guaiacol $(45 \mathrm{mM}), 50 \mu \mathrm{L}$ of $\mathrm{H}_{2} \mathrm{O}_{2}(22.5 \mathrm{mM})$, and $50 \mathrm{~mL}$ of citrate phosphate buffer solution $(0.5 \mathrm{M})$ in addition to $20 \mu \mathrm{L}$ of the crude enzyme extract. The absorbance was measured by a spectrophotometer at $470 \mathrm{~nm}$. One unit of enzymatic activity (U/mg) was defined as the amount of enzyme that catalysis the production of $1 \mu \mathrm{mol}$ of tetraguaiacol/min under test conditions (Şahin Ercan and Soysal, 2018).

Optimization of enzymatic activity with the sequential methodology

Effect of $\mathrm{pH}$ on peroxidase activity

POD activity was measured at variable $\mathrm{pH}(3,4,5$, 7,8 , and 9) using $0.5 \mathrm{M}$ citrate phosphate buffer solution. It consists of the preparation of a mixture optimization of the peroxidase extracted from the turnip. The sequential methodology is used in the first time to study the influence of three independent physicochemical parameters $(\mathrm{pH}$, temperature, and $\mathrm{NaCl}$ concentration) on $\mathrm{POD}$ activity in the turnip. Thereafter, the results are used to optimize POD activity with Surface Response Methodology. containing $50 \mu \mathrm{L}$ of guaiacol, $25 \mu \mathrm{L}$ of $\mathrm{H}_{2} \mathrm{O}_{2}$, $25 \mathrm{~mL}$ of citrate phosphate buffer $(0.5 \mathrm{M})$ with different $\mathrm{pH} 3-9$, and $20 \mu \mathrm{L}$ of the crude enzyme extract.

\section{Effect of temperature on peroxidase activity}

The solution of the reaction mixture contains 50 $\mu \mathrm{L}$ of guaiacol, $25 \mu \mathrm{L}$ of $\mathrm{H}_{2} \mathrm{O}_{2}$, and $25 \mathrm{~mL}$ of citrate phosphate buffer solution $(0.5 \mathrm{M}, \mathrm{pH} 6.0)$. After incubation for $10 \mathrm{~min}$ under different temperatures $\left(5-70^{\circ} \mathrm{C}\right)$, the crude enzyme extract was added and absorbance measurements are carried out every $1 \mathrm{~min}$.

\section{Effect of $\mathrm{NaCl}$ concentration on peroxidase activity}

The ionic strength influence on POD activity was measured at variable $\mathrm{NaCl}$ concentrations $(0.5-2$ M) using citrate phosphate buffer solution $\mathrm{pH} 6.0$ $(0.5 \mathrm{M})$ at fixed concentrations of guaiacol and $\mathrm{H}_{2} \mathrm{O}_{2}$.

\section{Optimization of enzymatic activity with Response surface methodology Experimental design}

In order to refine the optimal conditions for the peroxidase activity of turnip, an experimental design following the response surface methodology was carried out. For this, the BoxBehnken (BBD) design was used with three variables and factorial levels. The independent variables used were $\mathrm{pH}\left(x_{1}\right)$, temperature $\left(x_{2} ;{ }^{\circ} \mathrm{C}\right)$, and $\mathrm{NaCl}$ concentration $\left(x_{3} ; \mathrm{moL} / \mathrm{L}\right)$, while the dependent variable response was peroxidase activity. The results of optimization of POD activity by sequence methodology were used to show the levels of the three parameters: $\mathrm{pH}(0.5$ 1.5), temperature $\left(25-35^{\circ} \mathrm{C}\right)$, and $\mathrm{NaCl}$ concentration $(5-7 \mathrm{M})$ for optimization with RSM. The levels of the three factors were coded as + (low), 0 (middle), and - (high). The experimental design was conducted in duplicate (Table 1). 


\section{Construction and validation of the model}

The construction of the experimental plan and the analysis of data were achieved using JMP 10 software. The significance of the elaborated mathematic model was tested by analysis of variance (ANOVA) and the obtained data were fitted to a second-order polynomial model; regression coefficients of the response surface analysis were obtained according to the general equation (Eq. 1). $\alpha_{0}, \alpha_{\mathrm{i}}, \alpha_{\mathrm{ii}}$, and $\alpha_{\mathrm{ij}}$ are regression coefficients for intercept, linear, quadratic, and interaction terms, respectively; $x_{i}$ and $x_{j}$ are independent variables.

Optimal conditions of peroxidase activity of turnip depending on $\mathrm{pH}$, temperature, and $\mathrm{NaCl}$ concentration were predicted with the predictive equation of RSM. The optimal values obtained experimentally and calculated were compared in order to verify the validity of the model.

$$
y=\alpha_{0}+\sum_{i=1}^{3} \alpha_{i} x_{i}+\sum_{i=1}^{3} \alpha_{i i} x_{i}^{2}+\sum_{i=1}^{3} \sum_{j=1}^{3} \alpha_{i j} x_{i} x_{j}(i \neq j)(E q .1)
$$

\section{RESULTS AND DISCUSSION}

\section{Effect of pH on POD activity}

POD activity of turnip (Brassica rapa) was tested at variable $\mathrm{pH}$. As illustrated in Figure 1a, the best $\mathrm{pH}$ value is found around $\mathrm{pH}$ 6. Generally, most plants are characterized by a maximum enzymatic activity around neutral pH (Arnnok et al., 2010). For $\mathrm{pH}$ values above 9 and below 3, the POD loses almost completely its activity. This reduction of activity at extreme $\mathrm{pH}$ is due to the denaturation of enzymes (Amiour and Hambaba, 2016).

The optimum $\mathrm{pH}$ for enzymatic activity depends on plant material, substrate, and reaction medium (Arnnok et al., 2010; Rezaei et al., 2017). The optimum $\mathrm{pH}$ of Kiwifruit peroxidase, using $p$ phenylenediamine as substrate, is 6.0-8.5 (Fang et al., 2008), it is equal to about 5.0 for POD extracted from loquat and sapota fruits with guaiacol (Zhang and Shao, 2015), potato POD is

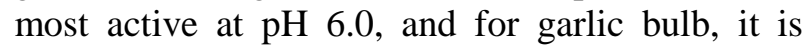
around $\mathrm{pH} 5.5$ to 6.5 with guaiacol as substrate (Cai et al., 2012), using the same substrate, the optimum $\mathrm{pH}$ of Ghars and Deglet Nour dates peroxidases are 6.4 and 5.6, respectively (Amiour and Hambaba, 2016). The optimum $\mathrm{pH}$ for chestnut peroxidase can reach up to $\mathrm{pH} 7.0$ with 2methoxy phenol as substrate (Gong et al., 2015).

\section{Effect of temperature on POD activity}

The use of different mediums with variable temperatures $\left(5-70^{\circ} \mathrm{C}\right)$ indicated a gradual increase of peroxidase activity with temperature increasing from 5 to $30^{\circ} \mathrm{C}$ and then quickly declined (Figure 1b). Beyond $50^{\circ} \mathrm{C}$, the POD completely inactivated. High temperatures will break the bonds responsible for maintaining the 3D structure of the enzyme that induces the modification of enzyme shape and consequently disrupts the active site. In this case, the enzymatic activity will be reduced or completely will be suppressed (Agostini et al., 2002; Sáez et al., 2019). The enzymatic activity usually depends on the temperature of the medium. Several studies have been devoted to study the influence of temperature on POD activity. The optimal temperature for peroxidases activity of sweet potato and lettuce is around $30^{\circ} \mathrm{C}$ and is $40^{\circ} \mathrm{C}$ for radish, garlic, sorgho, and dates (Saraiva et al., 2007; Diao et al., 2011; Amiour and Hambaba, 2016).

\section{Effect of $\mathrm{NaCl}$ concentration on POD activity}

The POD activity increased with $\mathrm{NaCl}$ concentration rising from 0 to $1 \mathrm{M}$ and then decreased for higher concentrations due to the modification of enzyme structure (Figure 1c). The most commonly used reagents for enzyme extraction are $\mathrm{NaCl}$ and buffer solutions. The $\mathrm{NaCl}$ increases the ionic strength of the buffer, which enhanced extraction of the plant enzymes. Plants possess hydrogen peroxide enzymes as POD and CAT, which lead to detoxification of reactive oxygen, thus protected cells against the harmful of hydroperoxides. Some authors reported that POD activity depends significantly on the salinity of the reaction medium (Dicko et al., 2006; Zeyadi and Almulaiky 2020).

\section{Analysis of the model}

The combination of the three factors $(\mathrm{pH}$, temperature, and $\mathrm{NaCl}$ concentration) as well as the observed (experimental) and predicted (predicted) of response (enzymatic activity) are summarized in Table 1. From the results, it can be observed that experimental values of enzymatic activity are close to that of predicted by the model. The results of the model analysis of the peroxidase activity optimization are listed in Tables 2 and 3. The regression coefficients (intercept, quadratic, linear, and interaction terms) of the mathematic 
model are resolved with the least square technique (Table 2). According to these results, the linear terms $x_{2}$ and $x_{3}$ and the three quadratic and the interaction terms $x_{1}-x_{2}$ are significant $(p<0.05)$, whereas the linear term of $x_{1}$ and the interactions $x_{1}-x_{3}$ and $x_{2}-x_{3}$ are not significant. It is indicated that the linear term of temperature, the three quadratic parameters, and the interaction of $\mathrm{pH}$ $\mathrm{NaCl}$ concentration terms influenced negatively the enzymatic activity. However, only $\mathrm{NaCl}$ concentration positively affected this activity.

The fitted quadratic model for peroxidase activity considering significant terms is given in equation 2 (Eq. 2):

Peroxidase activity (U/mg)

$$
=3726.23-20.55 x_{2}+498.94 x_{3}-46.60 x_{1} x_{2}-1076.32 x_{1}^{2}-48.62 x_{2}^{2}-2552.40 x_{3}^{2} \text { (Eq. 2) }
$$

$x_{1}: p H, x_{2}:$ temperature $\left({ }^{\circ} \mathrm{C}\right), x_{3}: \mathrm{NaCl}$ concentration $(M), *$ statistically significant $(p<0.05)$
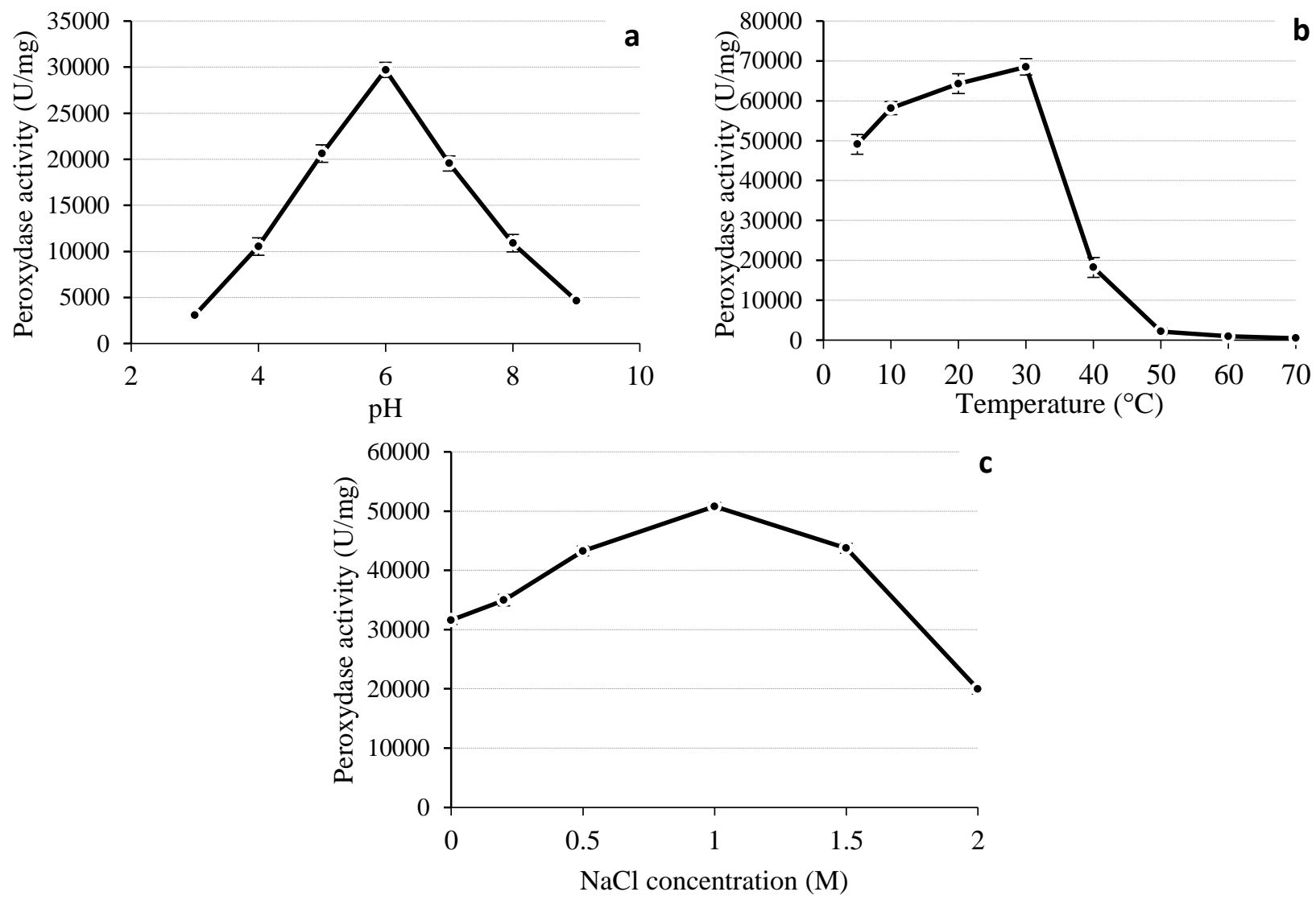

Figure 1. Influence of $\mathrm{pH}(\mathrm{a})$, temperature (b), and $\mathrm{NaCl}$ concentration (c) on turnip POD activity

Table 1. Box-Behnken design matrix of experiments runs and observed and predicted results of POD activity

\begin{tabular}{|c|c|c|c|c|c|}
\hline \multirow{2}{*}{ Run } & \multicolumn{3}{|c|}{ Variable levels } & \multicolumn{2}{c|}{ Enzymatic activity } \\
\cline { 2 - 5 } & $\boldsymbol{x}_{\boldsymbol{I}}$ & $\boldsymbol{x}_{\boldsymbol{2}}$ & $\boldsymbol{x}_{\boldsymbol{3}}$ & Observed & Predicted \\
\hline 1 & $5(-)$ & $25(-)$ & $1(0)$ & 1725.854 & 1601.069 \\
\hline 2 & $7(+)$ & $25(-)$ & $1(0)$ & 2154.853 & 2049.225 \\
\hline 3 & $5(-)$ & $25(-)$ & $1(0)$ & 1725.854 & 1601.069 \\
\hline 4 & $7(+)$ & $25(-)$ & $1(0)$ & 2154.853 & 2049.225 \\
\hline 5 & $5(-)$ & $30(0)$ & $1.5(+)$ & 2751.505 & 2634.364 \\
\hline 6 & $7(+)$ & $35(+)$ & $1(0)$ & 1291.925 & 1367.333 \\
\hline 7 & $6(0)$ & $30(0)$ & $1(0)$ & 4063.155 & 4009.188 \\
\hline 8 & $6(0)$ & $25(-)$ & $1.5(+)$ & 2100.611 & 2388.734 \\
\hline 9 & $6(0)$ & $30(0)$ & $1(0)$ & 4003.983 & 4009.188 \\
\hline 10 & $6(0)$ & $25(-)$ & $0.5(-)$ & 2085.818 & 2137.997 \\
\hline 11 & $7(+)$ & $35(+)$ & $1(0)$ & 1324.799 & 1367.333 \\
\hline 12 & $6(0)$ & $30(0)$ & $1(0)$ & 3872.489 & 4009.188 \\
\hline 13 & $6(0)$ & $30(0)$ & $1(0)$ & 4018.776 & 4009.188 \\
\hline
\end{tabular}




\begin{tabular}{|l|c|c|c|c|c|}
\hline 14 & $6(0)$ & $30(0)$ & $1(0)$ & 4092.741 & 4009.188 \\
\hline 15 & $5(-)$ & $35(+)$ & $1(0)$ & 1727.498 & 1851.206 \\
\hline 16 & $5(-)$ & $30(0)$ & $0.5(-)$ & 2118.692 & 1973.034 \\
\hline 17 & $6(-)$ & $25(-)$ & $1.5(0)$ & 1469.442 & 1601.069 \\
\hline 18 & $5(-)$ & $35(+)$ & $1(0)$ & 1763.659 & 1851.206 \\
\hline 19 & $5(-)$ & $30(0)$ & $0.5(-)$ & 1750.509 & 1973.034 \\
\hline 20 & $6(0)$ & $35(+)$ & $1.5(+)$ & 2087.462 & 2327.446 \\
\hline 21 & $7(+)$ & $30(0)$ & $0.5(-)$ & 1840.911 & 2211.178 \\
\hline 22 & $6(0)$ & $35(+)$ & $1.5(+)$ & 2608.506 & 2327.446 \\
\hline 23 & $7(+)$ & $30(+)$ & $0.5(-)$ & 2411.265 & 2211.178 \\
\hline 24 & $6(0)$ & $25(-)$ & $0.5(-)$ & 2149.100 & 2137.997 \\
\hline 25 & $5(-)$ & $30(0)$ & $1.5(+)$ & 2687.402 & 2634.364 \\
\hline 26 & $6(0)$ & $35(+)$ & $0.5(-)$ & 1880.359 & 1767.528 \\
\hline 27 & $6(0)$ & $35(+)$ & $0.5(-)$ & 1942.819 & 1767.528 \\
\hline 28 & $7(+)$ & $30(0)$ & $1.5(+)$ & 2342.231 & 2360.504 \\
\hline 29 & $7(+)$ & $30(0)$ & $1.5(+)$ & 2455.644 & 2360.504 \\
\hline 30 & $6(0)$ & $30(0)$ & $1(0)$ & 4003.983 & 4009.188 \\
\hline
\end{tabular}

$x_{1}: p H, x_{2}$ : temperature $\left({ }^{\circ} \mathrm{C}\right), x_{3}: \mathrm{NaCl}$ concentration $(\mathrm{M})$, peroxidase activity expressed as U/mg. *: statistically significant $(p<0.05)$

Table 2. Calculation and statistical significance check of regression coefficients of the peroxidase activity model

\begin{tabular}{|l|c|c|c|c|}
\hline \multicolumn{1}{|c|}{ Parameters } & Estimated & Standard error & t-ratio & Prob $>|t|$ \\
\hline Intercept & 3726.23 & 386.59 & 9.64 & $<0.0001^{*}$ \\
\hline$x_{1}$ & 67.09 & 44.85 & 1.50 & 0.1503 \\
\hline$x_{2}$ & -20.55 & 9.28 & -2.21 & $0.0387^{*}$ \\
\hline$x_{3}$ & 498.94 & 95.86 & 5.20 & $<0.0001^{*}$ \\
\hline$x_{1}-x_{2}$ & -46.60 & 12.34 & -3.78 & $0.0012^{*}$ \\
\hline$x_{1}-x_{3}$ & -256 & 12.39 & -1.98 & 0.0618 \\
\hline$x_{2}-x_{3}$ & 30.92 & 28.33 & 1.09 & 0.2882 \\
\hline$x_{1} * x_{1}$ & -1076.32 & 68.31 & -15.76 & $<0.0001^{*}$ \\
\hline$x_{2} * x_{2}$ & -48.62 & 2.72 & -17.87 & $<0.0001^{*}$ \\
\hline$x_{3} * x_{3}$ & -2552.40 & 273.25 & -9.34 & $<0.0001^{*}$ \\
\hline$x_{1}: p$ & &
\end{tabular}

$x_{1}: p H, x_{2}:$ temperature $\left({ }^{\circ} \mathrm{C}\right), x_{3}: \mathrm{NaCl}$ concentration $(\mathrm{M}), *$ : statistically significant $(p<0.05)$

The fitted data following the quadratic model are summarized in Table 3. The analysis of the variance of the developed peroxidase activity model denoted a high statistical significance with a probability lower than 0.0001 . This is supported by the high value of the correlation coefficient (0.9704) indicating that $97.03 \%$ experimental response is explained by the model and only less than three of $3 \%$ of the information is lost, attesting the goodness of the quadratic model for the POD activity. In addition, the checking of model lack of fit is found not significant $(\mathrm{p}=2.7221)$. This result implied that the mathematical model has a high performance for the prediction of the peroxidase activity of turnip.

\section{Response surface analysis}

In order to illustrate the interaction between the three studied variables and peroxidase activity, Figure 2 showed the graphical plots of the three- dimensional surface of the model. The effect of $\mathrm{pH}$ and temperature of the reaction medium on the response is given in Figure 2.a which indicates that both factors influenced together peroxidase activity. These latter increased until the optimum $\mathrm{pH}(5.9)$ and temperature $\left(29.8^{\circ} \mathrm{C}\right)$ and thereafter decreased. Plants peroxidase display an optimal enzymatic activity at temperatures ranging generally from 30 to $50^{\circ} \mathrm{C}$ and $\mathrm{pH}$ between 3 and 7 (Pandey et al., 2017). The effects of pH-NaCl concentration and temperature- $\mathrm{NaCl}$ concentration are shown in Figure $2 b$ and $c$. The quadratic effect is well observed for the studied parameters. This indicated that at high or low levels of these three factors, the peroxidase activity is reduced; the increase of these parameters induced the increase of the response, but beyond certain levels, an inverse effect is observed and this is due to the ionization or denaturation of the enzyme. 
Table 3. Analysis of variance for the peroxidase activity model.

\begin{tabular}{|l|c|c|c|c|}
\hline \multicolumn{1}{|c|}{ Source } & Degree of freedom & Sum of squares & F-ratio & Prob $>\boldsymbol{F}$ \\
\hline$x_{1}$ & 1 & 74909 & 2.2372 & 0.1503 \\
\hline$x_{2}$ & 1 & 163890 & 4.8947 & $0.0387^{*}$ \\
\hline$x_{3}$ & 1 & 907055 & 27.0898 & $<0.0001^{*}$ \\
\hline$x_{1}-x_{2}$ & 1 & 477556 & 14.2626 & $0.0012^{*}$ \\
\hline$x_{1}-x_{3}$ & 1 & 131074 & 3.9146 & 0.0618 \\
\hline$x_{2}-x_{3}$ & 1 & 39860 & 1.1905 & 0.2882 \\
\hline$x_{1} x_{1}$ & 1 & 8311763 & 248.2368 & $<0.0001^{*}$ \\
\hline$x_{2} * x_{2}$ & 1 & 10689979 & 319.2640 & $<0.0001^{*}$ \\
\hline$x_{3} * x_{3}$ & 1 & 2921390 & 87.2494 & $<0.0001^{*}$ \\
\hline Model & 9 & 21917617 & 2435291 & $<0.0001^{*}$ \\
\hline Lack of fit & 3 & 217298.98 & 72433.0 & 0.0767 \\
\hline Error & 20 & 669664.02 & & \\
\hline Total model & 29 & 22587281 & & \\
\hline Pure error & 17 & 452365.04 & & \\
\hline $\mathrm{R}^{2}=0.97$ & & & & \\
\hline Adj $\mathrm{R}^{2}=0.96$ & & & & \\
\hline
\end{tabular}

$x_{1}: \mathrm{pH}, x_{2}:$ temperature $\left({ }^{\circ} \mathrm{C}\right), x_{3}: \mathrm{NaCl}$ concentration $(\mathrm{M})$, *: statistically significant $(p<0.05)$
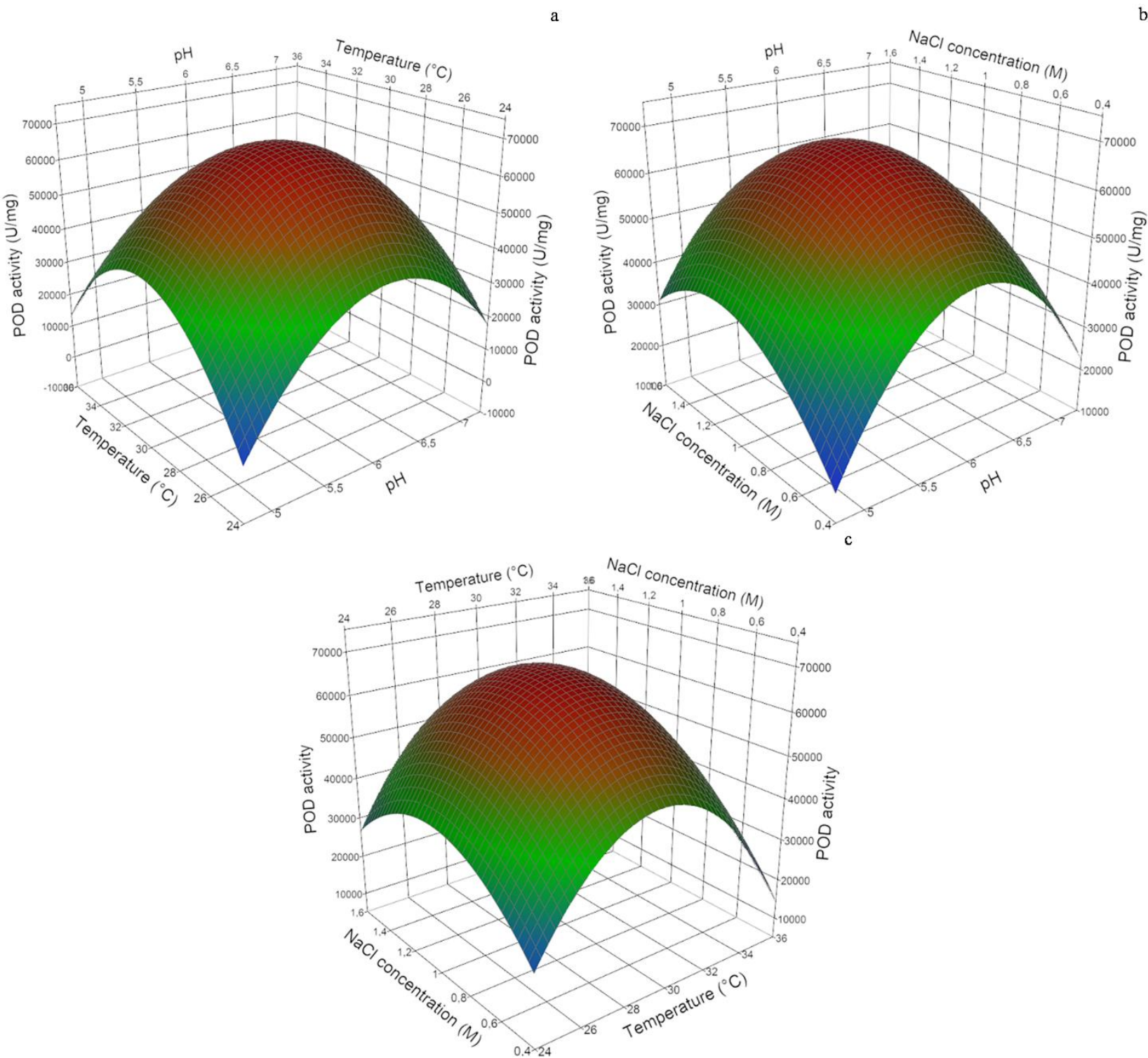

Figure 2. Three-dimensional response surfaces representing the influence of $\mathrm{pH}$-temperature (a), $\mathrm{pH}-\mathrm{NaCl}$ concentration (b), and temperature- $\mathrm{NaCl}$ concentration (c) on POD activity. 


\section{Model Verification}

Optimal values of three factors on peroxidase activity are obtained by the desirability profiler of JMP. The adequate conditions that manifested the highest peroxidase activity from the turnip are $\mathrm{pH}$ of 5.9 , the temperature of $29.8^{\circ} \mathrm{C}$, and $1.07 \mathrm{M}$ for $\mathrm{NaCl}$ concentration. Under these optimal conditions, the predicted enzymatic activity is $4027.25 \mathrm{U} / \mathrm{mg}$. The experimental test of these maximized conditions $(4031.10 \pm 23.77 \mathrm{U} / \mathrm{mg})$ indicated the agreement with the predicted value of peroxidase activity and attesting thus the validity of the developed quadratic model.

\section{CONCLUSION}

In this study, the sequential and response surface methodologies allowed to determine the optimal conditions for the activity of the peroxidases extracted from the turnip. The three studied parameters $(\mathrm{pH}$, temperature, and $\mathrm{NaCl}$ concentration) significantly influenced POD activity. The conditions that maximized POD activity are $5.9,29.8^{\circ} \mathrm{C}$, and $1.07 \mathrm{M}$, respectively. The observed POD activity is in agreement with the calculated value indicating the relevance of the established quadratic model for peroxidase activity.

\section{ACKNOWLEDGEMENTS}

The authors thank the Directorate General of Scientific Research and Technological Development (DGRSDT) for funding this work.

\section{REFERENCES}

1. Agostini, E., Hernández-Ruiz, J., Arnao, M.B., Milrad, S.R., Tigier, H.A. \& Acosta, M. (2002). A peroxidase isoenzyme secreted by turnip (Brassica napus) hairy-root cultures: inactivation by hydrogen peroxide and application in diagnostic kits. Biotech. Appl. Biochem. 35(1), 1-7. DOI: 10.1042/ba20010049.

2. Amiour, S.D. \& Hambaba, L. (2016). Effect of pH, temperature and some chemicals on polyphenoloxidase and peroxidase activities in harvested Deglet Nour and Ghars dates. Postharv. Biol. Techn. 111, 77-82. DOI:10.1016/j.postharvbio.2015.07.027.

3. Arnnok, P., Ruangviriyachai, C., Mahachai, R., Techawongstien, S. \& Chanthai, S. (2010). Optimization and determination of polyphenol oxidase and peroxidase activities in hot pepper (Capsicum annuum L.) pericarb. Int. Food Res. J. 17, 385-392.

4. Benkerrou, F., Louaileche, H. \& Bachir bey, M. (2018). Optimized ultrasonic-assisted extraction of total phenolics and antioxidant activity of date (Phoenix dactylifera 1.) using response surface methodology. The Annals of the University Dunarea de Jos of Galati. Fascicle VI-Food Technology. 42(2), 9-22.

5. Bradford, M.M. (1976). A rapid and sensitive method for the quantitation of microgram quantities of protein utilizing the principle of protein-dye binding. Analytic. Biochem. 72(1-2), 248-254. DOI: 10.1016/0003-2697(76)90527-3.

6. Cai, F., OuYang, C., Duan, P., Gao, S., Xu, Y. \& Chen, F. (2012). Purification and characterization of a novel thermal stable peroxidase from Jatropha curcas leaves. J. Mol. Catal. B Enzym. 77, 59-66. DOI: 10.1016/j.molcatb.2011.12.002.

7. Chisari, M., Barbagallo, R.N. \& Spagna, G. (2007). Characterization of polyphenol oxidase and peroxidase and influence on browning of cold stored strawberry fruit. J. Agric. Food chem. 55(9), 34693476. DOI: 10.1021/jf063402k.

8. Das, M.K., Sharma, R.S. \& Mishra, V. (2011). A novel cationic peroxidase (VanPrx) from a hemiparasitic plant (Viscum angulatum) of Western Ghats (India): Purification, characterization and kinetic properties. J. Mol. Catal. B Enzym. 71(1-2), 63-70. DOI:10.1016/j.molcatb.2011.03.010.

9. Diao, M., Kone, O.H., Ouedraogo, N., Bayili, R.G., Bassole, I.H. \& Dicko, M.H. (2011). Comparison of peroxidase activities from Allium sativum, Ipomoea batatas, Raphanus sativus and Sorghum bicolor grown in Burkina Faso. Afr. J. Biochem. Res. 5(4), 124-128. 
10. Dicko, M.H., Gruppen, H., Hilhorst, R., Voragen, A.G. \& van Berkel, W.J. (2006). Biochemical characterization of the major sorghum grain peroxidase. FEBS J. 273(10), 2293-2307. DOI: 10.1111/j.1742-4658.2006.05243.x.

11. Fang, L., Jiang, B. \& Zhang, T. (2008). Effect of combined high pressure and thermal treatment on kiwifruit peroxidase. Food Chem. 109(4), 802-807. DOI: 10.1016/j.foodchem.2008.01.017.

12. Garmakhany, A.D., Mirzaei, H., Aghajani, N. \& Kashiri, M. (2010). Investigation of natural essential oil antioxidant activity on peroxidase enzyme in selected vegetables. J. Agric. Sci. Technol. 4(3), 78-82.

13. Gong, Z., Li, D., Liu, C., Cheng, A. \& Wang, W. (2015). Partial purification and characterization of polyphenol oxidase and peroxidase from chestnut kernel. LWT - Food Sci. Technol. 60(2), 1095-1099.

14. Horotan, A. \& Oancea, S. (2013). Effects of fungicide and acetylsalicylic acid treatments on the physiological and enzymatic activity in tomato (Lycopersicon esculentum Mill.). Acta Univ. Cibiniensis, Ser. E: Food Technol. 17(1), 13-26. DOI: 10.2478/aucft-2013-0002.

15. Ikehata, K., Buchanan, I.D., Pickard, M.A. \& Smith, D.W. (2005). Purification, characterization and evaluation of extracellular peroxidase from two Coprinus species for aqueous phenol treatment. Biores. Technol., 96(16), 1758-1770. DOI: 10.1016/j.biortech.2005.01.019.

16. Manu, B. \& Rao, U.P. (2009). Calcium modulated activity enhancement and thermal stability study of a cationic peroxidase purified from wheat bran. Food Chem. 114(1), 66-71. DOI: 10.1016/j.foodchem.2008.09.028.

17. Onsa, G.H., bin Saari, N., Selamat, J. \& Bakar, J. (2004). Purification and characterization of membrane-bound peroxidases from Metroxylon sagu. Food Chem. 85(3), 365-376. DOI: 10.1016/j.foodchem.2003.07.013.

18. Pandey, S., Sharma, A.K., Solanki, K.P. \& Singh, S.P. (2018). Catalysis and stability of an extracellular $\alpha$-amylase from a haloalkaliphilic bacterium as a function of the organic solvents at different $\mathrm{pH}$, salt concentrations and temperatures. Indian J. Mar. Sci. 47, 240-248

19. Pandey, V. P., Awasthi, M., Singh, S., Tiwari, S. \& Dwivedi, U. N. (2017). A comprehensive review on function and application of plant peroxidases. Biochem. Anal. Biochem.6(1), 2161-1009. DOI: 10.4172/2161-1009.1000308.

20. Passardi, F., Bakalovic, N., Teixeira, F.K., Margis-Pinheiro, M., Penel, C. \& Dunand, C. (2007). Prokaryotic origins of the non-animal peroxidase superfamily and organelle-mediated transmission to eukaryotes. Genomics. 89(5), 567-579. DOI: 10.1016/j.ygeno.2007.01.006.

21. Pramana, Y. S., Sunarti, T. C. \& Purwoko (2018). Process Optimization for Dietary Fiber Production from Cassava Pulp Using Acid Treatment. Acta Univ. Cibiniensis, Ser. E: Food Technol. 22(2), 21-32. DOI: $10.2478 /$ aucft-2018-0009.

22. Rezaei, S., Shahverdi, A. R. \& Faramarzi, M. A. (2017). Isolation, one-step affinity purification, and characterization of a polyextremotolerant laccase from the halophilic bacterium Aquisalibacillus elongatus and its application in the delignification of sugar beet pulp. Biores. Technol. 230, 67-75. DOI: 10.1016/j.biortech.2017.01.036.

23. Saci, F., Benchikh, Y., Louaileche, H. \& Bachir bey, M. (2018). Optimization of ultrasound-assisted extraction of phenolic compounds and antioxidant activity from carob pulp (Ceratonia siliqua L.) by using response surface methodology. The Annals of the University Dunarea de Jos of Galati. Fascicle VI-Food Technology. 42(1), 26-39.

24. Sáez, L., Murphy, E., FitzGerald, R. J. \& Kelly, P. (2019). Exploring the use of a modified HighTemperature, Short-Time Continuous Heat Exchanger with Extended Holding Time (HTST-EHT) for thermal inactivation of trypsin following selective enzymatic hydrolysis of the $\beta$-lactoglobulin fraction in whey protein isolate. Foods. 8(9), 367. DOI: 10.3390/foods8090367.

25. Şahin Ercan, S. \& Soysal, C. (2018). Properties of Tomato Peroxidase. J. Adv. Plant Sci. 1, 206.

26. Saraiva, J.A., Nunes, C.S. \& Coimbra, M.A. (2007). Purification and characterization of olive (Olea europaea L.) peroxidase-Evidence for the occurrence of a pectin binding peroxidase. Food Chem. 101(4), 1571-1579. DOI:10.1016/j.foodchem.2006.04.012.

27. Serrano-Martínez, A., del Amor, F., Fortea, M. I., Lucas-Abellán, C., López-Miranda, S. \& NúñezDelicado, E. (2014). Effect of plant age and saline water on antioxidant and peroxidase activity in sweet pepper fruit. J. Agr. Sci. 6(12), 1-13. DOI: 10.5539/jas.v6n12p139.

28. Serrano-Martínez, A., Fortea, M., Del Amor, F. \& Núñez-Delicado, E. (2008). Kinetic characterisation and thermal inactivation study of partially purified red pepper (Capsicum annuum L.) peroxidase. Food Chem. 107(1), 193-199. DOI: 10.1016/j.foodchem.2007.08.028. 
29. Shu, G., Zhang, B., Zhang, Q., Wan, H. \& Li, H. (2016). Effect of temperature, pH, enzyme to substrate ratio, substrate concentration and time on the antioxidative activity of hydrolysates from goat milk casein by alcalase. Acta Univ. Cibiniensis, Ser. E: Food Technol. 20(2), 29-38. DOI: 10.1515/aucft2016-0013.

30. Tsapatsaris, S. \& Kotzekidou, P. (2004). Application of central composite design and response surface methodology to the fermentation of olive juice by Lactobacillus plantarum and Debaryomyces hansenii. Intern. J. Food Microbiol. 95(2), 157-168. DOI: 10.1016/j.ijfoodmicro.2004.02.011.

31. Vishwasrao, C., Chakraborty, S. \& Ananthanarayan, L. (2017). Partial purification, characterisation and thermal inactivation kinetics of peroxidase and polyphenol oxidase isolated from Kalipatti sapota (Manilkara zapota). J. Sci. Food Agric. 97(11), 3568-3575. DOI: 10.1002/jsfa.8215.

32. Yamaguchi, M., Kaseda, C., Yamazaki, K. \& Kobayashi, M. (2006). Prediction of blood glucose level of type 1 diabetics using response surface methodology and data mining. Med. Biol. Eng. Comput. 44(6), 451-457. DOI: 10.1007/s11517-006-0049-x.

33. Yim, H.S., Chye, F.Y., Koo, S.M., Matanjun, P., How, S.E. \& Ho, C.W. (2012). Optimization of extraction time and temperature for antioxidant activity of edible wild mushroom, Pleurotus porrigens. Food Bioprod. Process. 90(2), 235-242. DOI: 10.1016/j.fbp.2011.04.001.

34. Zeyadi, M. \& Almulaiky, Y. Q. (2020). A novel peroxidase from Ziziphus jujuba fruit: purification, thermodynamics and biochemical characterization properties. Sci. Rep. 10(1), 1-11. DOI: 10.1038/s41598-020-64599-9.

35. Zhang, B., Shu, G., Bao, C., Cao, J. \& Tan, Y. (2017). Optimization of Culture Medium for Lactobacillus bulgaricus using Box-Behnken Design. Acta Univ. Cibiniensis, Ser. E: Food Technol. 21(1), 3-10. DOI: 10.1515/aucft-2017-0001.

36. Zhang, X. \& Shao, X. (2015). Characterisation of polyphenol oxidase and peroxidase and the role in browning of loquat fruit. Czech J. Food Sci. 33(2), 109-117. DOI: 10.17221/384/2014-CJFS. 